\title{
Drawing Symbolism and Leadership
}

Like Chapter 3, this chapter deals with leadership and symbolism. The focus in this chapter is on drawing leadership and symbols. This chapter, like the one before it, is situated in the cognitive task of creation (Krathwohl, 2002). The theories and ideas of leadership and symbolism outlined in Chapter 3 can help frame the leadership and symbolism assignments in this chapter.

\section{LEADERSHIP EXERCISE}

The actions of leaders, both effective and ineffective, have been dissected by scholars and historians from time immemorial. The assignment below calls for students to select a leader and create a situation to illustrate. Teachers may want to give students a list of leaders. This can be done with famous (or infamous) leaders, assigned leaders and emergent leaders (Northouse, 2018). Studying emergent leaders may be a little trickier, but I think it would make a great assignment. Teachers and students could work to identify people who had no official power, but nevertheless exerted great influence. Further, the leader should be someone who is controversial, who students can really dig into and dissect. For example, a student could select the French Revolutionary leader Robespierre. Robespierre and the Committee of Public Safety did some questionable things during the Revolution. Nevertheless, upon further inspection, the short period

A. J. Letizia, Graphic Novels as Pedagogy in Social Studies, Palgrave Studies in Global Citizenship Education and Democracy, https://doi.org/10.1007/978-3-030-44252-1_5 
of the Committee's rule has many interesting facets as well. Robespierre and the Committee of Public Safety were pursuing the creation of a country based on the ideals of the Enlightenment. Palmer $(2017,45)$ asserts: "The Reign of Terror was by no means the Reign of Darkness. Quite the contrary, it was, among other things, an attempt to force a new enlightenment on the century." So I have selected Robespierre for this example.

The discussion of leadership theories from Chapter 3 is utilized for this assignment. Can Robespierre be cast as a servant leader? An authentic leader? How can Robespierre's actions be understood or presented in visual format? The assignment has students select episodes from Robespierre's rule and illustrate them. Students could also focus on symbols such as the guillotine to offer a new and different understanding of this period. As mentioned in the previous chapters, students must also consider character position, emotional responses, shading, panels, and encapsulation, nonlinear considerations, and synecdoche to truly convey a myriad of ideas.

A thematic statement can be of use here as well. A thematic statement is a sentence which captures the "unifying theme" of the story, is specific in nature, and contains a "primal element" such as love (Potts, 2013, 105). While the students are striving for accuracy in portraying the leader they chose, the students are putting their stamp on the work. The thematic statement can be used to achieve this task and give the students direction, as well as allow the teacher to see this direction early on. One student may think Robespierre is a monster, whereas another student may think he was an effective leader. When comics are finished, students can present them to the class and other students can give a critique or ask questions. (If done online, this can be done with comments on a discussion board.) Teachers will have to decide how to handle the presentation and discussion of student comics.

\section{Drawing Leadership Assignment}

Directions: You are to select scenes from the rule of a leader and illustrate those scenes. Answer the prompts below.

1. Write a thematic statement. What are you trying to show about your leader? Is he or she effective? Not effective? Cruel or kind?

2. Use the leadership chart. In your own opinion, what type of leader was this person? How did the person impact their people? Justify your answers. 
3. Encapsulation: Which scenes will you illustrate to capture what you wrote in the thematic statement? Why? What scenes are important to convey your message?

4. What features of the comic medium can you use to convey your message? (e.g., emotions and gestures, panel size, shape, and pacing).

5 . When you are finished with your comic you will present to the class. You must select two of your classmate's comics and write two questions for the creator.

Students however do not simply have to focus on existing leaders. Rather, they can create fictional leaders, alternate universes, or postapocalyptic stories to convey these meanings. If students do create fictional leaders, it may make sense to have these leaders parallel real-life leaders. So, a Robespierre-like figure may command a region or nation in a post-apocalyptic world (Jessica Abel recounts how she created a story which combined the ideas of Euripides and space travel!). The fictional leader, based on reality, can give the student room to explore themes and not have to worry about being historically accurate. Further, if students do create a fictional leader and have more room for creativity, the notion of a story arc may be incorporated. Abel and Madden (2008) and Potts (2013) talk about the importance of the story or narrative arc for comics (and good writing in general). A story arc is some type of event or situation which disrupts that normal situation of the protagonist. A number of occurrences between the protagonists and antagonists then take place. Finally, there is the climax and a resolution (Abel \& Madden, 2008, 127; Potts, 2013, 100). Teachers will most likely have to discuss the notion of a story arc, as well as protagonists and antagonists, with their students.

Along with the story arc, other writing conventions can be introduced (depending on how long the assignment will be) which may include the thematic statements, the notion of conflict and genre expectations (Abel \& Madden, 2008; Potts, 2013). Here, another component of the assignment can be added, which would be a question asking the student to compare and contrast the fictional leader that he or she created with the real leader that the fictional one was modeled on. So, if creating a fictional leader, the modified assignment below could be used. 


\section{Fictional Leader Creation Assignment}

Directions: You are to create a fictional leader which resembles a real-life leader you have read about. You will create a fictional world.

1. Flesh out a brief story arc. What is the status quo, what event propels your protagonist to action, what are these actions, and what is the resolution?

2. Use the leadership chart. In your own opinion, what type of leader was this person? How did the persons impact their people? Justify your answers.

3. Encapsulation: Which scenes will you illustrate to capture what you wrote in the thematic statement? Why? What scenes are important to convey your message?

4. What features of the comic medium can you use to convey your message? (e.g., emotions and gestures, panel size, shape, and pacing).

5. Compare and contrast this fictional situation to the real thing. How does your leader compare to the real leader you selected? Why did you choose to deviate or keep things the same?

6. When you are finished with your comic you will present to the class. You must select two of your classmate's comics and write two questions for the creator.

Below is another variation of the leadership assignment.

\section{Illustrate a Leadership Theory Assignment}

Directions: Consult the leadership chart (located in Chapter 3). The main objective of the assignment is to visualize a leadership theory (e.g., How does servant leadership or authentic leadership look?). Answer the following questions.

1. Pick a leadership theory. Draft a short story arc of a fictional story involving a leader of this type. Your leader can embody the attributes of the theory or he/she could be missing these attributes. What situation does your protagonist face? 
2. Take the story arc and turn it into a minicomic. Think of how you can use the comic medium to show attributes which might be difficult to convey in text alone. Be sure to consider:

(a) Encapsulated moments.

(b) Panel size, shape, and frequency.

(c) Emotions.

One more variation of this exercise can incorporate non-Western ideas of citizenship. In keeping with that I have written about Buddhism, teachers can require students to research and draw a comic about a Buddhist leader. There have been a number of Buddhist leaders throughout history. Asoka and the Dalai Lama are some examples. The above questions can be utilized to create this assignment. Teachers can also utilize the ideas discussed in Chapter 3. I have also added some tasks below which can help to compare and contrast Western ideas of citizenship with Buddhist ideas.

1. Compare the differences between the Buddhist leader you chose and a Western politician. How does the adherence to Buddhist principles differentiate the actions of the two?

2. Create a post-apocalyptic leader that embodies the qualities of Buddhist political ideas.

\section{Buddhist Advisor Assignment}

Another leadership activity is called Buddhist advisor. It might make sense to assign the reading activity in Chapter 3 and work through the Buddhist leadership lens above so students have some familiarity with Buddhist leadership ideas. In this activity, students must pretend to be an advisor to a leader and apply those ideas. Teachers can decide which leader this will be. Teachers could have students find a current event, identify a world leader who must make a controversial or tough decision, and pretend to be their Buddhist counsel. Or teachers could have students select a leader from history and have students give them Buddhist counsel. How would a Buddhist counsel Abraham Lincoln? Barack Obama? Students are then to illustrate what this advice-acted out by the leader-may look like in comic form. 
Directions: You are an advisor to a leader. You are also knowledgeable of Buddhism and this knowledge guides your counsel. Answer the following:

1. Utilize your deep well of Buddhist knowledge and insight. What counsel or advice would you offer this leader? Why?

2. How might your advice look if taken? Draw this comic form. (Think of how you can use emotions, linear and nonlinear elements, encapsulation, and other facets of the comic form to portray your ideas.)

3. Justify the stylistic choices you made.

\section{DrAWING VISION}

The notion of organizational vision, while perhaps not the sexist or exciting of terms, may align nicely with the comic form. Visions help point toward the future by drawing on the past (Kouzes \& Posner, 2017). Bolman and Deal $(2017,244)$ argue that a vision transforms organizational purpose "into an image of the future." An organizational vision is "how the organization will look when it is performing extremely well in relation to its environment and key stakeholders" (Bryson, 2011, 271). Visions should be related to the previous actions and decisions of the organization, but visions should be an inspiration which get people moving, the vision should be of a new and better world due to the actions of the organization fulfilling its mission. Visions can give direction, as well as foster people's dreams and hopes (Bryson, 2011, 282-284).

It could be argued that the term vision has an obvious affiliation with visual thinking. Bryson (2011) also notes that effective visions can make use of images and pictures. If vision is how the organization should look at its optimal state, and how the organization can positively change the world, why not draw this vision? Studying organizations is also an important part of any history curriculum-armies, governmental organizations, corporations, and nonprofit organizations have all played, and continue to play, a major role in historical and current affairs (Bolman \& Deal, 2017; Bryson, 2011). The assignment below has students consider organizations and where organizations might find themselves (or where students think they should find themselves) in the future. The assignment below helps students to think like leaders-vision is an important aspect 
to leadership and organizations (Bolman \& Deal, 2017; Bryson, 2011; Kouzes \& Posner, 2017). Note: in the first question, I have written American history. This question can read American history, another country's history or world history. In addition, teachers will most likely need to explain what a vision is and what it is meant to accomplish.

\section{Drawing Vision Assignment}

Directions: Answer the questions below.

1. Pick an organization that has played, and continues to play, an important part in American history. State what role it has played in American history.

2. Write a brief vision for this organization for the future. Where do you think this organization should go? How is this vision related to what has come before?

3. Now, illustrate this vision in comics form. Specifically, show:

(a) How the organization can actually get there (think realistically how the organization utilizes its past).

(b) What does the better world that the organization creates look like?

(c) Think about how you encapsulate this message, use sequence and/or nonlinear elements, stylistic elements, panel size, and other elements of the comic medium.

\section{Leadership Creation Field Trip}

Field trips can be wonderful learning activities. (I also covered some of this in the last chapter. This chapter specifically focuses on leadership.) The obvious drawbacks are time and money. But if schools do go on field trips (or even virtual ones), the use of comics as field trip activities may add a new twist. And while the above activities were created with a field trip in mind, they could just as easily be done without going on a field trip. Students could research the pertinent information and do the assignments. Further, I have used American Civil War sites as examples, but these assignments can be done with a variety of topics.

Learning from a historical site takes place in a variety of forms. There are written placards, artifacts (some real, some replicas), tour guides, 
informational movies, museums, and pamphlets among other things. There is so much information, even I get overwhelmed. But a neat way for students to organize the information can be to put it in visual form. This will most likely require some pre-organization by the instructor. The instructor will have to put some parameters on the assignment so the student does not become too overwhelmed.

The assignment below, specifically focuses on leadership because many times the actions of leaders are highlighted in some way shape or form. I created this assignment with Antietam National Battlefield in mind (I live in Maryland and am a frequent visitor here. I drag my kids here as well). This is true at almost any Civil War site. At Antietam, the actions of the relevant generals are the subject of most of the sites. The actions of General Robert E. Lee or the Union General Ambrose Burnside and many others are dissected by placards and tour guides. Their decisions (as well as factors out of their control such as natural conditions and army size) dictated the outcome of the battle (A good overview of the Battle of Antietam can be found here https://www.nps.gov/anti/index. htm). Teachers can have their students reflect on the decisions of these leaders and then illustrate episodes of the battle. Teachers could have students reflect on leadership qualities they see in the generals or prep them first with some leadership ideas and theories to look for by utilizing the leadership chart from Chapter 3. While there is a focus on leadership, students will obviously absorb factual information pertaining to the site as well. The teachers could require that the information be taken from placards or tour guides and that the students must write down or cite exactly where the information came from. I have created some questions below. These are specific to sites I have visited, but could obviously be adapted to a wide array of historical sites.

\section{Leadership Field Trip Assignment}

Directions: Pick three leaders or generals. Illustrate one scene depicting a decision each general made that had a decisive effect on the outcome of the battle and/or its aftermath. The scenes must be connected and show cause and effect. Show specifically where you learned your information (e.g., rifle exhibit in the museum). You must include facts, but you must reflect on those facts as well. Think about the leadership qualities the person was showing - or which qualities you think may have been absent. 
Try to show this in your illustration. Finally, explain why you chose to create the illustrations you did.

\section{Pick three leaders}

2. Draw three scenes which depict those leaders

3. Cite where you got the information from

4. Reflect on the information and the person's leadership qualities (or lack of them). Can you apply any ideas from the leadership chart?

5. Justify how and why these scenes are linked together

6. Draw a circle around the sequence. What larger themes were surrounding the leader's actions and choices?

7. Finally, justify your artistic choices.

An example of a satisfactory assignment might have a student draw Ambrose Burnside's struggle to capture the bridge which now bears his name (a brutal and bloody affair). Next the student may draw General Lee's decision to retreat toward Virginia and finally Lincoln issuing the Emancipation Proclamation. These events are all connected (albeit there are gaps). The students can explain the connection and the gaps, reflect on Lee, Burnside, and Lincoln's leadership qualities and how those leadership qualities helped to influence the outcome at Antietam. In addition, like in Chapter 4, teachers could have students draw a larger circle around the sequence to show how wider themes impacted the event in question. Finally, students could justify their artistic choices.

Another variation of this activity could involve a jam comic. A jam comic is where different students each take turn creating a panel in the comic (Abel \& Madden, 2008). The teacher could assign a group of students to create a comic. Each student could be responsible for a leader. Let's continue with Antietam. One student could be required to research Ambrose Burnside's actions at the battle and reflect on his leadership capabilities. Another student could be required to research General Lee's actions and leadership capacities at the battle. The third student could research Lincoln's reaction to the battle and aftermath. Each student would have to create a frame or frames to showcase their ideas. The same rules would apply here. The students would have to cite placards and park rangers to build their comic. Finally, the students would come together and find the most optimal way to combine 
their comics. There are endless variations of this exercise as well as various options for the teacher to consider. How many students should be in a group? How much information should the teacher assign? Should the teacher assign leaders or let students pick? How many frames should students draw? Should students be able to edit their comics or should teachers just require them to draw one or two frames and then combine them and see what results? Teachers will need to consider all of these questions for this assignment.

The above comics have focused on different leaders. However, it might also be advantageous to focus on one leader in more depth, which is what the assignment below does. Further, the above assignments focused on a specific event, the American Civil War, where the activity below takes a broader approach. I used my nine-year-old daughter as a test subject for this assignment. While this book is written mainly for high school and college students, my daughter was able to provide important feedback on the assignment - if she understood it, then a high schooler surely would be able to as well (Fig. 5.1). My daughter and I visited the home of James Buchanan, the 15th President of the United States. His home is located in Lancaster Pennsylvania. He served one term from 1857 to 1861. Marino and Crocco (2012) noted how the town of New Brunswick, New Jersey, which they chose to study as local history, is not as recognizable as other more well-known places. Yet, a great deal of history happened there. Similarly, Buchanan is not as recognizable as let's say Abraham Lincoln, but this I think made the assignment more interesting in some ways. Students presumably know more about famous presidents and leaders. But what about everyone else? What about mediocre or average leaders? These people had a role in events as well and it makes sense to study them. In fact, many of these mediocre or average leaders had a big hand in events, as did Buchanan (for better or for worse and with Buchanan, most agree it was for the worst). Teachers might do well to seek out interesting local leaders or people who are not as well-known and have students study their actions to show students that history is not simply the province of a few famous people.

\section{Leadership Field Trip Assignment \#2}

Directions: Consider the actions of James Buchanan. Look through the exhibits, watch the movie and listen to the tour guides to get an idea of James Buchanan's actions as well as the historical context. 


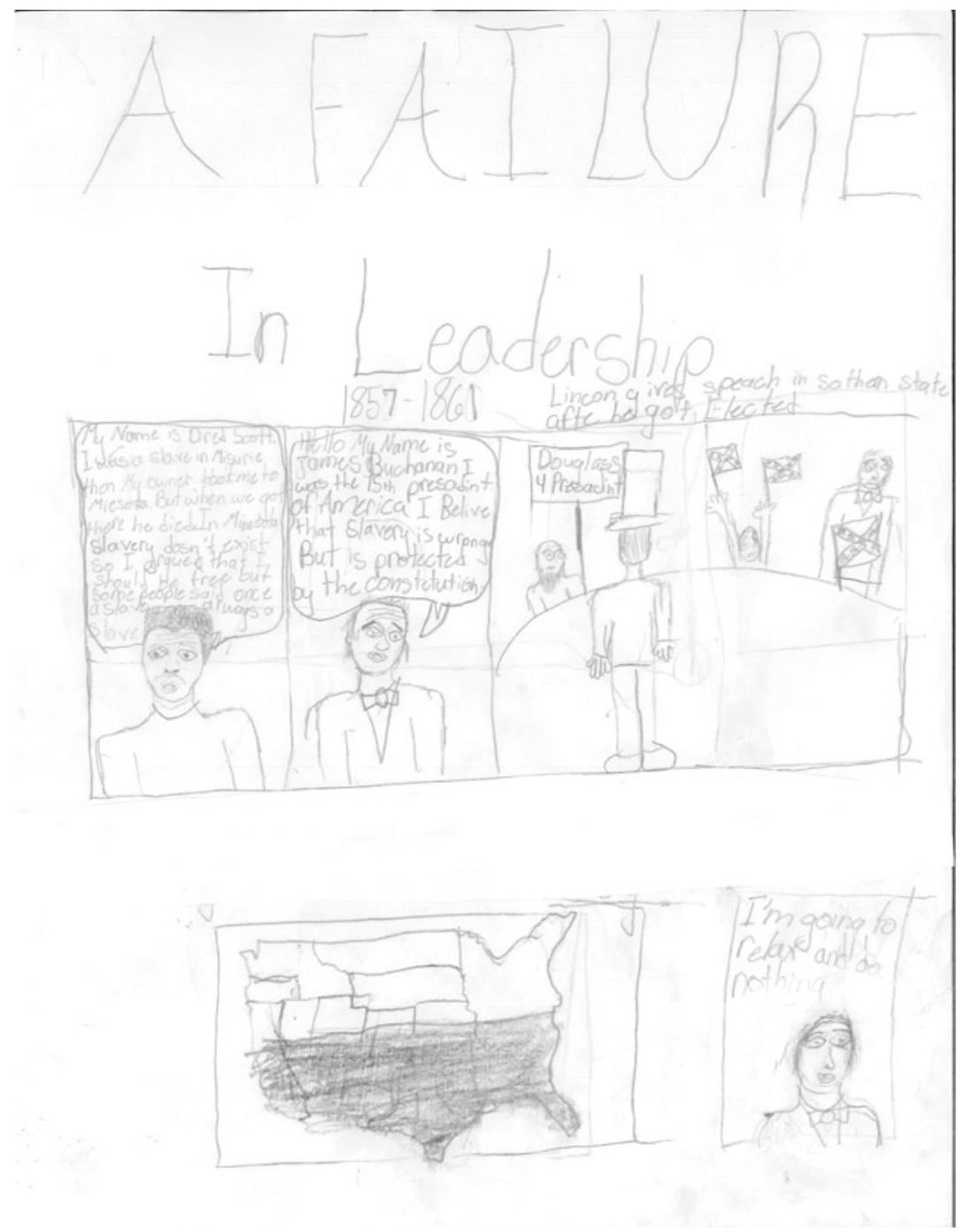

Fig. 5.1 Student example of leadership field trip assignment 
1. Identify three important events in Buchanan's presidency. State why you believe these are important.

2. Next, state how Buchanan's actions that you selected were influenced by the larger historical context.

3. Take each event above and create a three panel comic strip.

(a) The objective is to use sequential art to show cause and effect here. Show how events build off and impact each other.

(b) Consider which events you will encapsulate or show.

In discussing the project with my daughter, something became apparent to me. I had to stress the notion of encapsulation with her. Once she decided what scenes to show, she then had to figure out how to show it. While she is younger, I still think this an important point for anyone completing these projects. I stressed to her that she needed to choose what moments and pieces of the story to show, this was part of thinking through the project. I think the notion of encapsulation is important for all students. It helps students to tell the story of the past historical events.

\section{SYMBOLISM}

The next activities deal primarily with symbolism and imagery. Art note: It might be more convenient for students to utilize symbols-things that we all know-rather than images which are specific to their work (Schmidt, 2018), only because students comics will presumably not be that long and it will be more difficult to build in imagery. Nevertheless, I still think students can skillfully utilize imagery even in shorter comics, they just might have to work a little harder. In addition, as noted in Chapter 3, symbolism in comics can be in word, image, or story (Langley, 2018). Again, due to length, it might be easier for students to utilize visuals and words over stories to communicate symbolism but I think there is a place for story symbolism, at least for students who may want a challenge.

\section{JAM LAW COMIC}

The following activity is a type of jam comic (Abel \& Madden, 2008). I used this activity with my law class. As I stated in class regarding the assignment below, the purpose of this assignment is to harness the 
sequential abilities of comics to help students understand how law evolves. I was not only interested in actual occurrences, but also the symbolic nature, imagery, what is signified and deeper meaning of the events as well (Groensteen, 2013; Schmidt, 2018).

I gave the students a specific topic, which was ELL and immigrant education law. We had read a number of policies and cases spanning from the late 1960s to the 2000s. Obviously this topic is of current interest, so it makes for a fruitful discussion. Each group also had to present their comics to the class so we call could reflect on the comics and ask questions. The first student had to draw an earlier episode. One of the earliest policies we spoke about was the Civil Rights Act and one of the earliest cases we spoke about was Lau p. Nichols in 1974 (Imber, Geel, Blokhuis, \& Feldman, 2014). Students had to work together-and build off each other's ideas - to create a sequential story. Some ended with Donald Trump's now-infamous campaign speech where he stated that Mexicans were rapists, others ended by showing barbed wire on the border (Mark, 2018). This activity can be done with any topic or time period. As I stressed to my students, case law and policy does not happen in a vacuum, there are surrounding historical conditions. In addition, my class discussed on many occasions that policies and cases are not enough to change people, there also needs to be an attitudinal and moral shift for true change to occur. This activity allowed me to bring in a number of these points.

One group played with the notion of sequence. The group created a comic with geographic sequencing of sorts. One group member drew a map of the United States. The other members draw panels representing cases which took place in specific geographic regions, mainly Texas and California. As one student in the group told me, the group was trying to show how geography was an important factor in these cases. I thought this was a novel way to use the comic form. I think this method allowed my students to begin to visually represent and understand case law in new ways, which was the point of the assignment. They created a type of geographic sequence. This type of nontraditional sequence may also be an example of nonlinear capabilities of comics.

\section{Jam Law Comic Assignment}

Sequence is an important feature of the comic form (Eisner, 2002; McCloud, 1994; Potts, 2013). Successive frames/panel build off each 
other to tell a story. Policy and case law does not occur in a vacuum. Think of the ELL cases and policies we have studied in class. What sequence of events or ideas could you use to symbolize the progression of ELL policy and case law?

Think of concrete events and happenings (details of cases, cases themselves, policies).

Think also of how symbolism and imagery can be used to portray some of the bigger ideas of the case (what symbols could we use to represent these big ideas?).

\section{Directions:}

a. Get into groups of 3 or 4 people.

b. The first person draws something from our readings and discussions. This should be an earlier event/idea, etc.

c. The second person then draws something from a later date of our ELL discussion. This frame should be logically linked to the first frame.

d. The third person then draws something from an even later date of our ELL discussion. This frame should be logically linked to the second frame.

This is called a jam comic (Abel \& Madden, 2008), it is when each person contributes a frame. The point here is to utilize the sequential capability of comics to tell a story about ELL education, policy and cases, as well as attitudes and norms toward ELLs which may hinder or drive some of these policies.

\section{Thinking in Symbols}

This exercise utilizes the powerful symbolism of certain legal and national symbols. Dayton (2012) describes the meaning behind Lady Justice. Her blindfold represents equality before the law, the scales represent deliberation, and the sword represents enforcement. As noted in Chapter 3, Justice Jackson, in the landmark majority opinion for West Virginia State Board of Education v. Barnette in 1943, also noted the power of symbols. He wrote that the use of symbols such as flags or emblems act as "a short cut from mind to mind." Jackson also comments on the variable nature within symbols and how different people react differently to the same 
symbols: "A person gets from a symbols the meaning he puts into it, and what is one man's comfort and inspiration is another's jest and concern" (West Virginia State Board of Education v. Barnette, 1943). As noted previously, symbols can carry different meanings for different individuals, this is the notion of multivocality (Gill \& Angosto-Ferrandez, 2018).

Indeed, the Barnette case was fought over symbols. These passages can act as a segue into a larger discussion of national symbols, such as flags, emblems, as well as images such as lady justice. The graphic novel Uncle Sam, created by Alex Ross and Steve Darnell is replete with these types of symbols. Uncle Sam, the Soviet Bear, the French Marianne, all come into play. I have also mentioned Alan Moore and David Lloyd's use of Lady Justice in $V$ for Vendetta. The assignment below is meant to get students thinking with national symbols and creating their own.

First students look at and read about traditional symbols. Next, students are to manipulate existing symbols to convey a message about a specific case. The purpose of this component is for students to play with existing symbols, much like Ross and Darnell did. Uncle Sam and other traditional American (and other countries) symbols take on different and varied meanings in Uncle Sam. I want students to reconsider entrenched symbols. This can be done by writing about it or by drawing it.

Finally, students create their own symbols and images, but they must create a symbol with a sequence metaphor to accomplish this last task. A sequence metaphor, as noted earlier, is when two images are used to convey meaning, yet both images are needed to make sense. One image in isolation does not convey the message (Duncan, Smith, \& Levitz, 2015). Evans (2016) examines an excellent example of a sequence metaphor from a Superman comic. In one panel Superman is not present, and a young, frail girl is contemplating suicide. In the next panel, Superman appears. Evans (2016) writes "From his absence in the first panel to his then appearance in the second, it is incredibly powerful to witness what Superman, as a symbol, has the ability to do in helping this young girl." We discussed sequence metaphors in class and I had students read the except from Duncan and colleagues as well as Evans. This is what I want my law students to exploit- the use of sequential frames and specifically sequence metaphors to create meaning in regard to the law and its symbols.

For this exercise, I also provide an example that I have created. My example consists of two frames. The first frame has what seems to be a 
random collection of items. There is an armband, a newspaper, and banner, a speech bubble with the phrase "sexual innuendo," a banner with the word "Jesus" on it, a computer, and a boy standing with his arm raised. The next panel contains the same items (except there is a girl sitting at a desk while the pledge of allegiance is being recited), but this time, the backdrop is the constitution, specifically the lst amendment. Further, the computer, the banner, the speech bubble, and the newspaper all have a line going through them. There is a caption that reads "The law finds its expression in the oddest of places." I have attempted to create a sequence metaphor. The six items by themselves do not mean much, they only have a meaning when juxtaposed together with the second image and the understanding of the lst amendment. These items refer to cases that I assign to my students to read. The cases are: West Virginia State Board of Education v. Barnette (1943), Tinker v. Des Moines Independent Community School District (1969), Bethel School District no. 403 v. Fraser (1986), Hazelwood School District v. Kublmeier (1988), Morse v. Frederick (2007) and Kowalski v. Berkeley County Public Schools (2011) (this case was not a Supreme Court case). The items all have to do with the details of each case. The West Virginia case centered on whether compulsorily flag salutes were constitutional. The court said they were not. The Tinker case centered on students protesting the Vietnam War by wearing armbands to school. The court said this was protected speech. The Hazelwood case centered on the freedom of the press in school publications. The court ruled that the principal, who pulled two articles from the school newspaper, did not violate students' first amendment rights. The Bethel case centered on the students' use of lewd speech. The court said that lewd speech is not protected. The Frederick case was about student expression related to drug use at school supervised events. The court ruled that schools can discipline student speech related to drug use at these events (Oyez, n.d.). The Kowalski case hinged on off-campus speech via social media and cyberbullying. In this case it was permissible for the school to discipline the student who created a MySpace page which bullied another student (Imber et al., 2014). Dayton (2012, xiii) argues how the law is predicated on abstract notions but at the same time "governs every aspect of our daily lives from birth through death." I assign this passage to my students, and we discuss it in class. My sequence metaphor tries to convey this idea that we are working with extremely abstract and philosophical ideas, but they find expression in everyday situations (e.g., armbands, banners, etc.). 
In addition, this assignment was assigned in a hybrid summer course. My course is 10 weeks long. Six of those meetings are face to face and four of those meetings are asynchronous modules online. Part of this assignment was presented during a face-to-face session. I had also assigned the Dayton excerpt in the first week of class. During the second week of class, I had students read the Barnette excerpt (they were assigned the whole case, but for class, I just had them focus on the Jackson excerpt). I also provided them with a portion of Uncle Sam. Finally, I had them read the excerpt on sequence metaphors. The next day I posted follow up information to our in-class discussion. I sent them the Evans (2016) excerpt to read and view (since this one had excellent visuals). I also sent them more information on comic's theory (the cheat sheet). Putting some of the assignment online helped to convey more information. I was able to send and post follow-up ideas for students to have access to.

Finally, I showed them my example which I drew by hand. The next week, as part of their assigned online module assignment, students had to create their own sequence metaphor and post it to a discussion board. They were then supposed to offer comments on another classmate's sequence metaphor. I have found that sometimes it is good to give students some time to think about what to draw. Similar to wait time (Chapin, 2015), I think students simply need time to think and process what to draw and what symbols to use. I even need time to think about it. In fact, I had become frustrated for this assignment because I could not think of a good sequence metaphor. So, I put it away and then the idea randomly hit me as I was grocery shopping with my wife and daughter. So, I present the idea early, give students my expectations, and then let the ideas germinate. In addition, I wanted to see how some of these assignments will look online. Online education should be stimulating and intellectually challenging (Quality Matters Website, 2019), and I felt that symbol creation would be a great way to accomplish this feat. In addition, as I write this, the COVID-19 pandemic is raging and almost all schools, both K-12 schools and institutions of higher education, are moving their lessons online. In the future, as schools turn more to online education, I believe that comic activities can be one means of providing more challenging and meaningful online activities. As noted earlier, reflection on a piece of arts-based research is good practice (Barone \& Eisner, 2012). With an online discussion board, students can reflect on their own work and other's work as well. The last question has students commenting on 
other students' work online. In class, when we meet again, we then go through the comments and have a face to face discussion.

\section{Sequence Metaphor Assignment}

\section{Directions:}

1. Read the passages from Dayton (posted in week one, in-class readings folder) and Justice Jackson in the Barnette case. Read the excerpt from Uncle Sam. In your own words, how might symbols be used to convey legal ideas? What are the advantages and disadvantages to the use of symbols to convey legal ideas?

2. Can you manipulate any existing symbols to convey a message about any of the cases we have read? (So, use Ross and Darnell as a guide. Can you think of ways to reinterpret Uncle Sam, Lady Justice, or even Smokey the Bear or other American symbols to convey an idea about the cases you were assigned to read?). Note: this does not have to be drawn, it can be written.

3 . Read the excerpt on sequences metaphors distributed in class. Also go to https://whynotsuperheroes.com/tag/understandingcomics/. This is a blog by a comics theorist, Chris Evans. DO NOT read the whole thing. Simply hit Control $\mathrm{F}$ which will bring up a search box. Search the term "Sequence Metaphor." Read the brief section on sequence metaphors. (There is also a nice visual component to this.)

4. Create a sequence metaphor drawing on the cases we have read. Consult my example for inspiration, which is posted in Joule. THIS COMIC SHOULD BE AT LEAST 2 PANELS (like my example). We want to showcase the sequential nature of comics and meaningmaking.

5. Post your answers to questions 1 and 2 , as well as your comic from question 4, to the discussion board marked "symbol reflection." Comment on a classmate's comic. In your comment, try to reflect on what message you think the person is conveying.

When we met as a class in our next face-to-face meeting, we spent time discussing the comics. I had each student present their comic to the class. Members of the class commented on the comics and asked questions. This 
may have been somewhat redundant since we had already done something similar on the discussion board, but I wanted to have a comment session in both modalities, online and face to face. I think both modalities generated an interesting conversation. In the face-to-face setting, students were able to ask spontaneous questions and learn even more about their classmate's use of symbols. One student remarked how illustrating cases also helped her remember the cases. To be sure, not everyone loved the drawing component, but all the students did a great job and were able to articulate their use of symbols clearly. A student example is featured in Fig. 5.2. Notice how she utilized the "schoolhouse gate" reference from the Tinker Supreme Court Case.

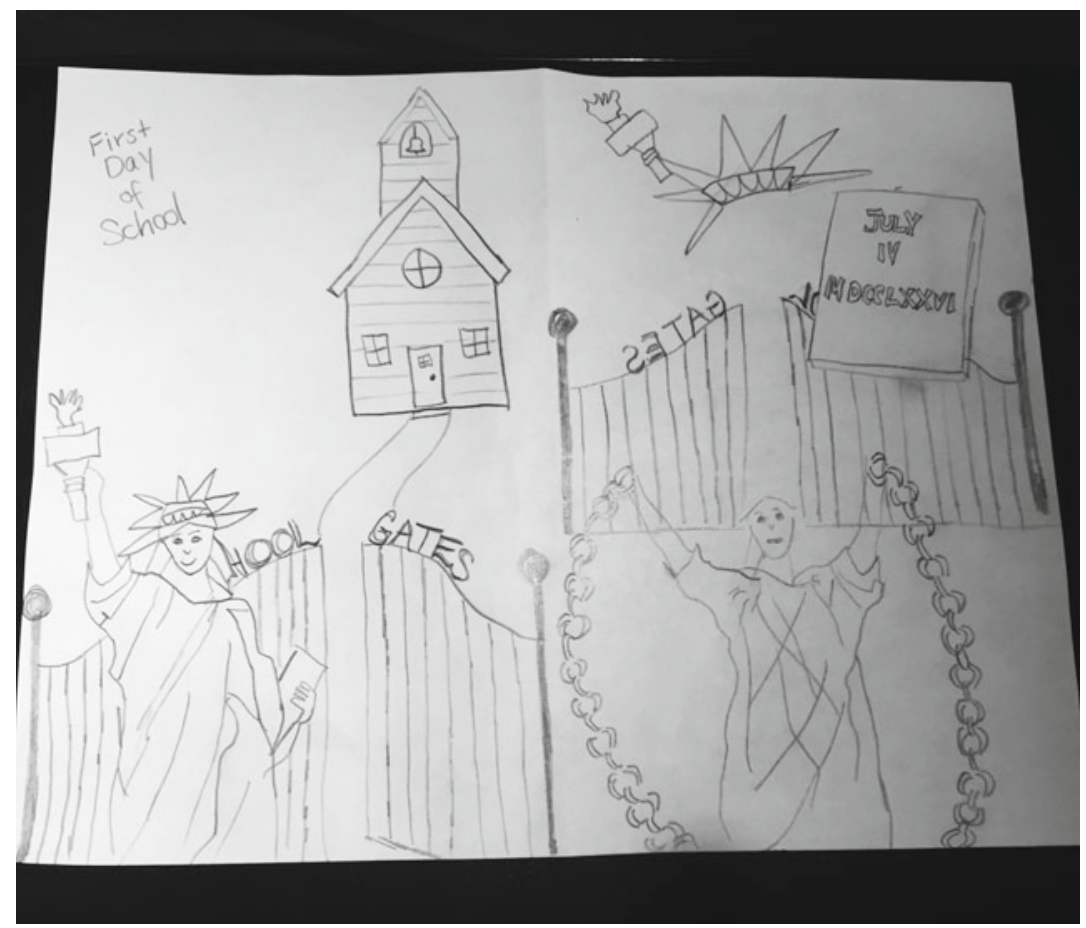

Fig. 5.2 Student example of sequence metaphor 


\section{Constellation Symbol Activity}

Arnheim (1997) writes: "A symbol gives particular shape to types of things or constellations of forces" (Arnheim, 1997, 138). Arnheim's ideas of symbolism served as inspiration for this assignment. I utilized this definition to create my own assignment. A symbol stands for a constellation of forces. But what does this actually mean? For this assignment, it means that symbols are more than what they denote, there is not a simple one to one correspondence. These symbols can be personal symbols as well as political symbols. I started with a personal symbol from my own life to illustrate the point. I use this example in class.

My home is a symbol to me. It symbolizes my family, good neighbors, a feeling of safety and security, a sanctuary of sorts. It also represents anxiety, in the form of my monthly mortgage as well as constant little worries about things breaking and needing repair. The point is that when I think of my home, it represents a constellation of things to me. Next, we turn to political symbols. The President of the United States (and the presidential seal) may be another type of symbol. The notion of president (depending on who occupies the office) can mean multiple things; good leadership, bad leadership, a paragon of morality, or a buffoon. Any understanding of symbols will obviously contain a high degree of subjectivity. Nevertheless, it can make for fruitful discussions. Teachers and instructors can have a discussion on how symbols can be constellations and give examples prior to students completing the assignment.

\section{Constellation Symbolism Assignment}

Directions: For this assignment, we will work with a specific definition of symbolism. Rudolf Arnheim (1997, 138) asserts that: "A symbol gives particular shape to types of things or constellations of forces." We will consider how symbols can denote a constellation of forces.

1. Think of a personal symbol to you which is loaded with meaning. Sketch out the various meanings of a highly personal symbol to you. These meanings may be contradictory, that is okay. Draw the initial symbol and then draw the constellation of forces it represents above it.

2. Now, do the same thing as you did in question number one, but think of a legal symbol. Some examples could be: US President, 
America, or The Constitution. Try to incorporate some of the ideas we have discussed in class (e.g., amendments, different court cases, etc.).

3. Now, make it sequential! Take your political symbol and build a short comic (at least two frames) with it.

4. Explain why you chose to depict the constellation of forces in this way.

5. Comment on one classmate's comic. When you comment, record your impressions to the symbols used. What emotions or ideas do those evoke in you?

I assigned this exercise to my Education Law class which is a hybrid class consisting of online and face-to-face meetings. Like the previous exercise, I introduced the assignment during one of our face-to-face sessions and had them complete it as part of the next online meeting. When I introduced the assignment, I also provided the comics cheat sheet. I created and posted my own comic (as a discussion post) as an example for students. My comic focused on the symbol of the US president. In the left panel, I drew what I felt were two inept US presidents William G. Harding and James Buchanan. In the middle panel, I drew two presidents, who are usually considered some of the most effective (but of course this is debatable). Abraham Lincoln and Franklin D. Roosevelt. Behind each president is a symbol of what made their presidency awful or great for me. For example, behind Buchanan I drew a picture of the United States breaking in half. The final panel simply pictures the presidential seal. I have tried to visualize the constellation of forces that the symbol of "US president" may stand for.

\section{Culminating Symbolism Activity}

What follows is a culminating activity in my history of education class. In fact, this activity was the final. This activity could easily be adapted to any history class either at the secondary or college level. While it will vary for any teacher or professor, this activity took me roughly a month to get through. Prior to this project, my class was run like most history classes are probably run. Students were assigned textbook readings, articles, and primary sources. In class we discussed those readings. I believe we had some great discussions (or the students could have been bored to death), but either way, the class was more traditional. During the 
comic book assignment, I was able to venture out a little. During this project, I stressed to my students that what they were doing aligned in many ways with Arnheim's (1997) notion of visual thinking, Barone and Eisner's (2012) notion of arts-based research, as well as Duncombe's (2019) notion of the ethical spectacle and Duncombe and Lambert's (n.d.) idea of art activism. I think student-created comics can be a GPS of sorts through hyperreality, a way to orient citizens through bullshit. This is how students can envision this assignment. Students were not creating something with no connection to reality, but rather, using the real, whether that was historical analysis, theories, or whatever, to create something better. Their comics were empirical in that sense because they drew on real-life ideas, but ultimately the comics used the real to disrupt the status quo or point to something better.

As I have stressed throughout this book, I make comics along with my students. This is good practice (Carter, 2013; Thompson, 2018). So I would periodically show excerpts from my graphic novel (which I have included in the appendix). I used my own work to give examples regarding symbolism and imagery as well as different ways to construct a comic. In some cases, students incorporated my ideas into their own comics.

The overarching objective of this assignment (which draws on Duncombe, Duncombe and Lambert, Barone and Eisner, the theories of citizenship laid out in Chapter 1 and other ideas in the text) is to utilize the comics medium to create a new world on the page or critique an aspect of the existing world, as it pertains to what we learned in class. Further this creation and/or critique will make use of symbolism and imagery, and the related ideas of sequence metaphors, symbols as constellations, nonlinear elements, and stereotypes. When creating symbols and imagery, it is also important to stress that art can have a number of meanings (Duncombe \& Lambert, n.d.). Student art does not have to specifically mean one thing or another, but can and should be left open to interpretation.

During the assignment, one of my students worried that she wasn't writing a traditional story. I told her that it was okay because we were more focused on symbolism, but her comment did give me pause. This assignment could incorporate the notion of story arc (Potts, 2013) as discussed previously in this chapter. However, teachers should not overload students with too many components. Nevertheless, story elements could be introduced into this assignment. I do think it important to point out however that students are not only drawing with symbols, but most likely, 
will utilize words. As noted in Chapter 1, this is a fruitful feature to create meaning.

Here is the assignment that I gave to my students. The assignment is composed of two components. The first component is the comic, and the second component is the creation of a tangible object. Both components made up the final for my class. The first component is divided into three parts. (LNDL is an acronym for the library at my university, the Loyola Notre Dame Library.) Please note, I have slightly modified and updated the assignment since I gave it to my class. The changes are small and the overall assignment is essentially the same. The small changes reflect my ongoing understanding of comics theory. I assigned this assignment to my undergraduate history of education in 2019 and then again the following year. I am using what I learned in the first iteration of the assignment to strengthen it the second time around.

Assignment: This assignment has two components which need to be submitted. The first component is an 8-page minicomic that you will create. The second component is a tangible artifact that you will create using one of the LNDL libraries' various creation technologies. The artifact will be something that you drew, referenced, or alluded to in your comic.

Objective: To utilize the comics medium to create a new and more just world on paper, or critique an aspect of the existing world as it relates to what we learned in class this year. Further this creation and/or critique will make use of symbolism and imagery.

A note on art. This is NOT a fine arts class. As such you will not be judged on your drawing ability. I will assess you on specific points of comic creation (see rubric).

\section{Component I. The Comic}

First you must decide what you will draw. You have wide latitude here. Below are some ideas to get you thinking. (But don't worry, we will complete some practice exercises first to get you warmed up. Then we will come back to drawing the comic). Below are some initial ideas to ponder. You can choose one of these ideas. However, if you want to do a combination of these or something of your own choosing, I strongly encourage that! Before you draw, you must first write a thematic statement (Potts, 2013,105 ) which briefly outlines the "unifying theme" of the story, to give you some direction. Or, more appropriately for this project, you must write a "dream statement." The dream statement is a succinct statement 
of the dream you will create in comic form. Remember, this is a dream of a better world that inspires people to act or some type of criticism to get people thinking.

1. You can illustrate a scene from the history of education (e.g., the creation of Mount Holyoke, a typical day Sunday School, etc., Thaddeus Stevens speaking to the Pennsylvania assembly). If you choose this option, be sure to add your own elements to the scene. How can you use this scene to challenge an injustice?

2. You can illustrate a fictional scene for a real person (Susan B. Anthony teaching fellow suffragettes, Thaddeus Stevens arguing with a racist person).

3. You can illustrate a scene of historical fiction.

4. You can conceive of a futuristic or even post-apocalyptic situation to illustrate (e.g., the downfall of the United States).

Other ideas....Write initial dream statement here:

When creating a comic, you can think of the big idea or scene and then break that down into components (each component is a panel or frame. See my examples). Think about what you want to highlight; which parts of the story are important for the reader to see. Think of sequence or how each scene you draw will be related to the previous and subsequent scene. Remember, you are drawing symbols and imagery. Some ways to break down the scene and consider are:

1. Panel size, shape, and frequency (think of Sousanis here).

2. Facial expressions and body language of characters.

3. Color (if applicable), shading, and line work.

4. Word and image interaction (do they complement each other, work against each other?).

5. What is shown, what is NOT shown

6. Consider what type of effect your images may have on the reader.

7. Multidirectionality, multilinearity, and braiding/translinerity (Cabero, 2019; Groensteen, 2007).

8. Onomatopoeia and word depiction/lettering.

The final product will be a hand-drawn, 8-page minicomic. This can be done in black and white or color. All comics will be scanned and uploaded to a WordPress website. 


\section{Component II}

The second part of the assignment has students make something from their comic real. Students are to use the library's various technologies to bring to life an aspect of their comic. The library offers a number of creative applications which are listed below.

1. Embroidery machine.

2. Cricut paper machine.

3. Button maker.

4. 3-D printer.

5. A-V technologies (recording and video creation).

If we take what is drawn as a representation of an idea, then this portion of the assignment is to make that representation tangible. Students must use one of the above technologies to make something real. For example, groups can create a campaign button, piece of a wardrobe, act out a newscast, or create a hornbook, among other things.

Below are three practice exercises which will be undertaken PRIOR to drawing the comic.

\section{Reading chart}

In the first section, briefly enumerate the main insights from each reading. In the second section, list examples of where you find any of the ideas in the readings in actual comics/graphic novels. Be specific of what you found and where you found it. 


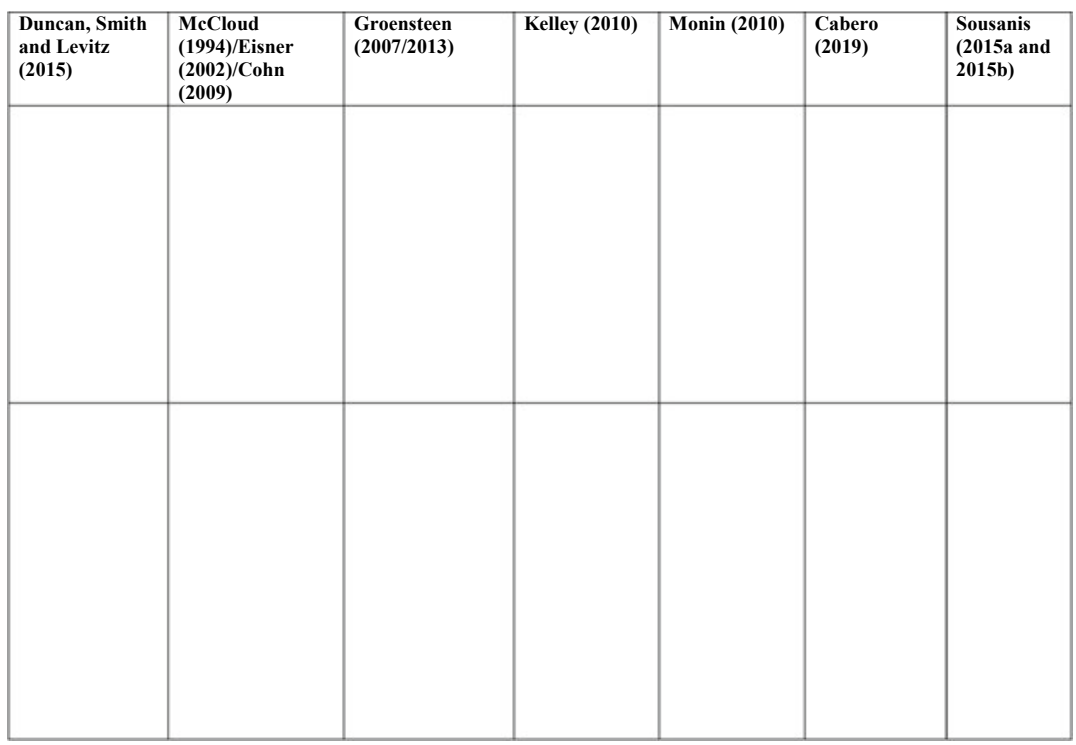

\section{Frame drawing exercise}

Read the excerpt from Cohn, Sousanis, Eisner. Panel size and shape help to dictate the story. The page as a unit is crucial, we make meaning from all the elements on the page as well as the page as a whole. For this practice exercise, first:

Draw some panels which correspond to some aspects of your daily routine (Sousanis, 2015a). Panel size and can dictate reading pace as well as elapsed storytime (however, there is some question equating panel size to elapsed time). How would you show an aspect of your day in panels?

Then pick a scene from history. Apply the frame drawing insights to it. How would you represent Thaddeus Steven's speeches in just panel size and shape? Justify your panel choices. Why did you choose the panel sizes and shapes you did? How did the panel size and shape help to convey information about the scene you choose? 
Add some expressive lines to further help convey your message (Sousanis, 2015a).

\section{Encoding the Spectacle}

Comics can be seen as encoded messages which are then read by the reader (Duncan et al., 2015).

Consider Duncombe's (2019) notion of the spectacle. Politics cannot rely solely on the Enlightenment notion of logical and scientific truth. We now need stories to tell the truth in the political arena. Politicians need to appeal to people's hopes and dreams. To be sure, politicians and progressives are not to lie to people, just use stories and fantasy to point people to the truth. "Reality is always refracted through the imagination" (Duncombe, 2019, 18).

Consider Barone and Eisner (2012) ideas of arts-based research. We can use art to disrupt the status quo and point to a better world. Duncombe (2019) says something similar as well, spectacles, while not the new world, at least point to it.

Consider symbolism, imagery, and stereotypes, as well as sequence metaphors, constellations, and translinear elements in comics (Arnheim, 1997; Cook \& Frey, 2017; Duncan, 2012; Evans, 2016; Gill \& AngostoFerrandez, 2018; Groensteen, 2013; Mandaville \& Avila, 2009).

Consider Westheimer and Kahne's (2004) three types of citizenship.

The overarching question is in italics. The questions below the italics help to refine the question.

How might you be able to create a new way to look at history and reality, one which aligns with a justice-oriented citizenship, by using the symbolic potential of comics to encode a message which helps people interpret a truth or disrupt the status quo?

1. How can symbols and spectacles promote justice and fairness? Or further oppression?

2. Now think specifically of your comic. Brainstorm some ideas that you may want to represent.

(a) Think first of the big idea you want to convey and then how that idea might be broken down into different scenes/aspects. What aspects would you show? Why? 
(b) Think of what symbols or images you can use to represent this idea or scene. Why did you choose those symbols? What do you they mean to you? To everyone else? How do those symbols help to promote justice and fairness or tell an important story?

(c) Think specifically of how you can utilize some of the different aspects of a comic/graphic novel to portray your symbol (shading, emotion, panel size, nonlinear considerations).

(d) How do all of these elements relate to your "dream" statement? (It is okay to make changes at this stage. You can rewrite the statement if need be).

EDU 402 Final

Directions: Answer each question on the WordPress site we created. Answers to questions 2-4 should be roughly a paragraph long (5-6 sentences). Answers to question one will vary.

1. Post each page of your comic on the WordPress site.

2 . For each page of your comic that you upload, create a very brief description. In this description (no more than 2-3 sentences) summarize the action and justify one stylistic choice you have made.

3. Consider how your comic may be a new way to look at history which incorporates aspects of things we discussed in class. When answering this question, please be sure to address the sub-questions below:

(a) What ideas from the class did you draw on to create your comic?

(b) How might your comic illuminate a truth or use aspects of the truth to posit something better?

4. Pick one other person's comic and read it. When answering this question, please be sure to address the sub-questions below:

(a) What messages did you receive from it? Justify your answers with evidence.

(b) How might this comic be a new way to see? 
5. Upload a picture of the object you created. Why did you choose to create the tangible object you did?

\section{Checklist}

The minicomic (this needs to be uploaded to the WordPress as well as scanned and put on Joule).

The reflection assignment (see above). The answers to this are posted on the WordPress site.

Your tangible object. You need to take a picture and upload to the WordPress site.

Here is the rubric (Epstein, 1997; Novak, 2014, 162) used to evaluate student work. I will go into more detail regarding the assessment and evaluation process in the next chapter. Rubric for Minicomic

\begin{tabular}{|c|c|c|c|c|}
\hline & 4 & 3 & 2 & 1 \\
\hline $\begin{array}{l}\text { Narrative/historical } \\
\text { understanding }\end{array}$ & $\begin{array}{l}\text { Narrative is } \\
\text { clear and } \\
\text { coherent/narrative } \\
\text { is } \\
\text { original/narrative } \\
\text { shows clear } \\
\text { understanding } \\
\text { of historical } \\
\text { topics while } \\
\text { utilizing } \\
\text { fictional or } \\
\text { fantastic } \\
\text { elements }\end{array}$ & $\begin{array}{l}\text { Narrative is } \\
\text { clear and } \\
\text { coherent for } \\
\text { the most } \\
\text { part/narrative } \\
\text { demonstrates } \\
\text { understanding } \\
\text { of historical } \\
\text { events but } \\
\text { some historical } \\
\text { discrepancies } \\
\text { while utilizing } \\
\text { fictional or } \\
\text { fantastic } \\
\text { elements }\end{array}$ & $\begin{array}{l}\text { Overall there is } \\
\text { clarity, but } \\
\text { much confusion } \\
\text { which detracts } \\
\text { from the } \\
\text { narrative/some } \\
\text { historically } \\
\text { accurate points } \\
\text { but there is } \\
\text { also much } \\
\text { confusion over } \\
\text { historical facts } \\
\text { while utilizing } \\
\text { fictional or } \\
\text { fantastic } \\
\text { elements }\end{array}$ & $\begin{array}{l}\text { There is no } \\
\text { clarity in the } \\
\text { narrative/there } \\
\text { is little } \\
\text { historical } \\
\text { understanding }\end{array}$ \\
\hline
\end{tabular}


(continued)

\begin{tabular}{|c|c|c|c|c|}
\hline & 4 & 3 & 2 & 1 \\
\hline $\begin{array}{l}\text { Use of comics } \\
\text { medium }\end{array}$ & $\begin{array}{l}\text { Use of the } \\
\text { comics medium } \\
\text { (e.g., panels, } \\
\text { encapsulation, } \\
\text { sequence, } \\
\text { nonlinear } \\
\text { considerations, } \\
\text { multilinearity, } \\
\text { multidirectionality, } \\
\text { SVS, etc.) helps } \\
\text { communicate } \\
\text { ideas and } \\
\text { information }\end{array}$ & $\begin{array}{l}\text { Use of the } \\
\text { comics medium } \\
\text { (e.g., panels, } \\
\text { encapsulation, } \\
\text { sequence, } \\
\text { nonlinear } \\
\text { considerations, } \\
\text { multilinearity, } \\
\text { multidirectionality, } \\
\text { SVS, etc.) for } \\
\text { the most part, } \\
\text { communicate } \\
\text { ideas but there } \\
\text { are some } \\
\text { instances of } \\
\text { confusion }\end{array}$ & $\begin{array}{l}\text { Use of the } \\
\text { comics medium } \\
\text { (e.g., panels, } \\
\text { encapsulation, } \\
\text { sequence, } \\
\text { nonlinear } \\
\text { considerations, } \\
\text { multilinearity, } \\
\text { multidirectionality, } \\
\text { SVS, etc.) does } \\
\text { communicate } \\
\text { ideas, but is } \\
\text { lacking in } \\
\text { certain } \\
\text { instances }\end{array}$ & $\begin{array}{l}\text { Use of the } \\
\text { comics medium } \\
\text { (e.g., panels, } \\
\text { encapsulation, } \\
\text { sequence, } \\
\text { nonlinear } \\
\text { considerations, } \\
\text { multilinearity, } \\
\text { multidirectionality, } \\
\text { SVS, etc.) lacks } \\
\text { design and } \\
\text { does not } \\
\text { communicate } \\
\text { any messages }\end{array}$ \\
\hline $\begin{array}{l}\text { Interanimation } \\
\text { of words and } \\
\text { images (if } \\
\text { applicable) }\end{array}$ & $\begin{array}{l}\text { Words and } \\
\text { images are not } \\
\text { redundant, } \\
\text { both convey } \\
\text { appropriate } \\
\text { meaning }\end{array}$ & $\begin{array}{l}\text { Words and } \\
\text { images, for the } \\
\text { most part, are } \\
\text { not redundant }\end{array}$ & $\begin{array}{l}\text { Some } \\
\text { redundancy } \\
\text { between words } \\
\text { and images }\end{array}$ & $\begin{array}{l}\text { Images are } \\
\text { redundant, text } \\
\text { does all the } \\
\text { work }\end{array}$ \\
\hline Images & $\begin{array}{l}\text { Images are } \\
\text { powerful and } \\
\text { help to convey } \\
\text { political/historical } \\
\text { meaning. } \\
\text { Strong } \\
\text { symbolism and } \\
\text { imagery is used } \\
\text { to convey ideas }\end{array}$ & $\begin{array}{l}\text { Images are } \\
\text { powerful and } \\
\text { help to convey } \\
\text { political/historical } \\
\text { meaning for } \\
\text { the most } \\
\text { part/For the } \\
\text { most part, } \\
\text { strong } \\
\text { symbolism and } \\
\text { imagery is used } \\
\text { to convey ideas }\end{array}$ & $\begin{array}{l}\text { Images are } \\
\text { clear and help } \\
\text { to convey some } \\
\text { political or } \\
\text { historical } \\
\text { meaning, but } \\
\text { some of the } \\
\text { images are } \\
\text { confusing or } \\
\text { need } \\
\text { explanation }\end{array}$ & $\begin{array}{l}\text { The images do } \\
\text { not properly } \\
\text { convey any } \\
\text { meaning, there } \\
\text { is confusion } \\
\text { about what } \\
\text { they convey }\end{array}$ \\
\hline
\end{tabular}

Included is a rubric which I discuss in detail in the next chapter. There are also questions that I posit for teachers to consider the citizenship impact of the piece. These questions are located in Chapter 6. Further, whether a rubric or questions, I believe that evaluation for this project should always be an ongoing conversation.

Specifically, I try to get my students to conceive of themselves as symbol creators. Students encode symbols and ideas into their comics (Duncan et al., 2015). In class discussions I linked the spectacle to citizenship, specifically Westheimer and Kahne's (2004) notion of justiceoriented citizenship. I posed the question of how the spectacle could be utilized to practice justice-oriented citizenship. I think this all centers on imagination. In an email correspondence, Duncombe also stated 
that he believes there is a crisis in imagination (Duncombe, email communication, April 26, 2019). Indeed, Wolk (2007, 133) bluntly states: "One gauge of the goodness of comics is how much they excite the imagination- what the reader perceives beyond and between the border of their panels." Needless to say, I think comic creation can fire the imagination in new ways. Weiner $(2007,69)$ also talks about the "hegemony of realism" which is a state of affairs where it is believed the future cannot be very different from the present. This hegemony can be broken with "transgressive acts of the imagination" (Weiner, 2007, 69). I contend that comics can be this transgressive act.

I created the assignments in Part I, II, and III to guide my students and allow them some real practice with features of the comic medium. These three introductory exercises helped to scaffold the main assignment of the final comic creation. For Part I, I assigned specific readings (see Part I). From these readings, I was able to discuss and examine the various scholarly aspects of comics with them. Following Brugar, Roberts, Jimenez, and Meyer (2018), I had students examine actual comics and try to locate some of the things they read about, such as closure, frame construction to names a few ideas.

For Part II, I utilized Sousanis's (2015a) grid drawing exercise. Sousanis highlights the importance of the actual frames in comics and has participants in his exercise draw panels which correspond with their daily routines. He tries to impress on his participants that the size of the panel can impact how one experiences the story. As I did in the last chapter, I also gave students the example from Jesse Cohn's (2009) chapter, where Cohn highlighted how Joe Sacco used a crowded panel arrangement to convey a sense of constriction. Sousanis also had his participants begin to add some expressive lines (but not actual representational drawings) which I had my students do as well.

I had my students complete Sousanis's exercise first. Then I modified it and added a political element to it. I told them to use panels to express or represent a political idea that we had talked about in class. I gave an example on the board to get them thinking. I compared the Obama presidency to the Trump presidency. For Obama, I drew five equal-size frames. For Trump, I drew five erratic and asymmetrical frames. The point was to show how erratic, contradictorily, and just plain crazy the Trump presidency is compared to the even keel, predictable (if not a little boring, see Duncombe) Obama presidency was. This comparison lent itself nicely to the frame drawing exercise. My students then represented many aspects 
from the history of education, most of which blossomed into full fledge ideas later on. One student began to experiment with frames and lines to convey historical notions, specifically racism. The Sousanis exercise can call attention to both diegetic time and reader pacing. As mentioned in Chapter 1 , it is important to note that while larger panels do generally mean a larger portion of time, this is not a hard and fast rule.

Next we spoke about symbolism, the spectacle, and justice-oriented citizenship (see exercise III). By this stage, students should have a clearer idea of their project. The purpose of the three introductory exercises is to provide a scaffold which leads students toward the final exercise. Some of these introductory exercises may not be needed in every class and initial project ideas can change as students become more familiar with the comics medium. I did not have them complete the separate exercise as listed in Part III because I felt the students were ready to draw. And draw they did. I will come back to my students' actual creation shortly. First I want to briefly discuss the second component of the project.

Earlier in the year, I was sitting at a required professional development where some of our media specialists were presenting on library technology. One of the librarians presented on the libraries' maker space and 3-D printing technologies which got me thinking about applications in my history classes. Eventually, I combined those ideas with the comic project. The second component of the comic project has the students take something from their comic and make it tangible. I wanted them to bring part of their spectacle to life. I included this component because I believe that the creation and interpretation of tangible things are important considerations for citizenship (Gilman-Forlini, 2018; Ratto \& Boler, 2014). I think this component also helps students to utilize new types of technology to convey their ideas.

By creating something tangible from their comic, my students could at least start to think about how tangible things can be encoded with political and critical meanings. Much like comics, meanings are invested into things, but viewers (or readers) create their own meanings, and these meanings can change over time. Their assignment called for them to bring something to life from their comic using the libraries technology. Some made buttons, some used the embroidery, others used the 3-D printers. I brought my students to the library where the technology specialist gave them an overview of each of the technologies they could utilize. The students had to go to the library on their own time to create their tangible artifact. 
In addition to this library session, I brought the students in for the second session. In the second session, another technology specialist helped us as a class to create a WordPress site. The intent for this component as for the students to gain some media literacy (me as well!). The class final was done entirely on the WordPress site. This was not a simple how-to, our media specialist also gave a mini lesson on how internet technology actually works, which was helpful for all of us to see and situate how the WordPress site actually operated.

The final was basically a reflection piece. Barone and Eisner (2012) talk about the importance of reflection in arts-based research. We must reflect on created works of art (be they plays painting, etc.) to truly understand them. This reflection adds a new layer of meaning. I stressed this with my students. I had them reflect on their own work. I also had them explain how their work might be an ethical spectacle or dream (Duncombe, 2019). In addition, I also had them articulate how exactly they grounded their comic in the real by describing what ideas they took from the course and how they used them to build their comic. Finally, I had them reflect on their created object.

Each student produced a unique, thought-provoking comic. Each comic was grounded in real ideas that we discussed as a class during the year, but each comic challenged the reader to think about a new world or think more deeply about an existing situation. I discuss some of their comics in detail in the next chapter. While I would like to say that this assignment was perfect-it was not. No assignment ever is. This however was the first iteration. I had to address some historical interpretations with students. Sometimes symbols could convey a misleading historical ideabut I had to balance this with the fact that students can use symbols and images in novel ways to create new ways to see history. I tried to stress with my students that what they created were new ways to see history and the present that aligned with justice-oriented citizenship ideas, and further, and that they challenged injustice in new ways.

\section{Descriptions for Figures}

Figure 5.1: This is an example of a student-created comic for the Leadership Field Trip Assignment. This comic was actually created by my nineyear-old daughter. In this sequence, she depicted the Dred Scott decision, Buchanan's reaction, the election of Abraham Lincoln, the beginning of the Civil War, and Buchanan's reaction. 
Figure 5.2: This is an example of a student-created comic for the Sequence Metaphor Activity. In this comic, the student played on the symbol of the Statue of Liberty. The Statue of Liberty represents freedom and invitation but also represents oppression and assimilation. My student also utilized an image of a schoolhouse gate in her sequence metaphor which was made famous in the West Virginia State Board of Education v. Barnette Supreme Court case.

\section{REFERENCES}

Abel, J., \& Madden, M. (2008). Drawing pictures \& writing words: A definitive course from concept to comic in 15 lessons. New York: First Second.

Arnheim, R. (1965/1997). Visual thinking (35th anniversary printing). Berkeley, CA: University of California Press.

Barone, T., \& Eisner, E. (2012). Arts based research. Thousand Oaks, CA: Sage.

Bolman, L. G., \& Deal, T. E. (2017). Reframing organizations: Artistry, choice, and leadership (6th ed.). San Francisco: Jossey-Bass.

Brugar, K., Roberts, K., Jimenez, L., \& Meyer, C. (2018). More than mere motivation: Learning specific content through multimodal narratives. Literacy Research and Instruction, 57(2), 183-208.

Bryson, J. M. (2011). Strategic planning for public and nonprofit organizations: A guide to strengthening and sustaining organizational achievement (4th ed.). San Francisco: Jossey-Bass.

Cabero, E. (2019). Beyond linearity: Holistic multidirectional, multilinear and translinear reading in comics. The Comics Grid: Journal of Comics Scholarship, $9(1): 5,1-21$.

Carter, J. B. (2013). "What the-?" Pre-service teachers meet and grapple over graphic novels in the classroom. In C. Syma \& R. Weiner (Eds.), Graphic novels and comics in the classroom (pp. 58-72). Jefferson, NC: McFarland.

Chapin, J. (2015). A practice guide to middle and secondary social studies (4th ed.). New York: Pearson.

Cohn, J. (2009). Mise-en-page: A vocabulary for page layouts. In S. Tabachnick (Ed.), Teaching the graphic novel (pp. 44-57). New York: Modern Language Publishing.

Cook, M., \& Frey, R. (2017). Using superheroes to visually and critically analyze comics, stereotypes, and society. SANE Journal: Sequential Art Narrative in Education, 2(2), Article 1. Retrieved from https://digitalcommons.unl.edu/ sane/vol2/iss $2 / 1$.

Dayton, J. (2012). Education law: Principles, policies, and practices. Lexington, KY: Wisdom Buildings Press. 
Duncan, R. (2012). Image functions: Shape and color as hermeneutic images in Asterios Polyp. In M. Smith \& R. Duncan (Eds.), Critical approaches to comics: Theories and methods (pp. 43-54). New York: Routledge.

Duncan, R., Smith, M., \& Levitz, P. (2015). The power of comics: History, form and culture (2nd ed.). New York: Bloomsbury.

Duncombe, S. (2019). Dream or nightmare: Reimagining politics in an age of fantasy (2nd ed.). New York: OR Books.

Duncombe, S., \& Lambert., S. (n.d.). Why artistic activism: Nine reasons. The Center for Artistic Activism. Retrieved from https://c4aa.org/2018/04/ why-artistic-activism/.

Eisner, W. (2002). Comics and sequential art: Principles and practices from the legendary cartoonist. New York: W. W. Norton.

Epstein, T. L. (1997). Social studies and the arts. In W. Ross (Ed.), The social studies curriculum: Purposes, problems, and possibilities (1st ed., pp. 137-164). Albany, NY: SUNY Press.

Evans, J. C. (2016, January 5). A rhetorical quest for identity. https:// whynotsuperheroes.com/tag/understanding-comics/.

Gill, G., \& Angosto-Ferrandez, L. F. (2018). Introduction: Symbolism and politics. Politics Religion and Ideology, 19(4), 429-433. https://doi.org/10. 1080/21567689.2018.1539436.

Gilman-Forlini, J. (2018, Fall). The role of monuments and historic preservation. Baltimore Gaslight: Newsletter of the Baltimore City Historical Society, 17(2). Retrieved from https://staticl.squarespace.com/ static/58b4b8216a49630b430ldf9f/t/5c2f9855562fa7f325f9b95c/ $1546623065034 / 2018+2$.pdf.

Groensteen, T. (2007). The system of comics (B. Beaty \& N. Nguyen, Trans.). Jackson, MS: University of Mississippi Press.

Groensteen, T. (2013). Comics and narration. Jackson, MS: University of Mississippi Press.

Imber, M., Van Geel, T., Blokhuis, J. C., \& Feldman, J. (2014). Education law (5th ed.). New York: Routledge.

Kelley, B. (2010). Sequential art, graphic novels, \& comics. SANE Journal: Sequential Art Narrative in Education, 1(1), Article 1.

Kouzes, J. \& Posner, B. (2017). The leadership challenge: How to make extraordinary things happen in organizations (6th ed.). Hoboken, NJ: Wiley and Sons.

Krathwohl, D. (2002). A revision of Bloom's taxonomy: An overview. Theory into Practice, 41(4), 212-218.

Langley, J. (2018, July 1). Symbolic power among marvels. Psychology Today. Retrieved from https://www.psychologytoday.com/us/blog/beyond-heroesand-villains /201807/symbolic-power-among-marvels. 
Mandaville, A., \& Avila, J. (2009). It's a word! It's a picture! It's comic! Interdisciplinary approaches to teaching comics. In S. Tabachnick (Ed.), Teaching the graphic novel (pp. 245-254). New York: Modern Language Publishing.

Mark, M. (2018, April 5). Trump just referred to one of his most infamous campaign comments: Calling Mexicans "rapists." Business Insider. Retrieved from https://www.businessinsider.com/trump-mexicans-rapistsremark-reference-2018-4.

Marino, M. P., \& Crocco, M. S. (2012). Doing local history: A case study of New Brunswick, New Jersey. The Social Studies, 103, 233-240. https://doi. org/10.1080/00377996.2011.630697.

McCloud, S. (1994). Understanding comics. New York: Harper Perennial.

Monin, K. (2010). Teaching graphic novels: Practical strategies for the secondary ELA classroom. Mankato, MN: Maupin House Publishing.

Northouse, P. G. (2018). Leadership: Theory and practice (8th ed.). Los Angeles: Sage.

Oyez. (n.d.). Oyez. Retrieved from https://www.oyez.org/.

Novak, R. J. (2014). Teaching graphic novels in the classroom: Building literacy and comprehension. Waco, TX: Prufrock Press.

Palmer, R. R. (1941/2017). The twelve who ruled: The year of terror in the French Revolution (updated edition). Princeton, NJ: Princeton University Press.

Potts, C. (2013). The DC comics guide to creating comics: Inside the art of visual storytelling. New York: Crown Publishing.

Quality Matters Website. (2019). Retrieved from https://www.qualitymatters. org/index.php/why-quality-matters/value-to-students?

Ratto, M., \& Boler, M. (2014). Introduction. In M. Ratto \& M. Boler (Eds.), DIY citizenship: Critical making and social media (pp. 1-22). Cambridge, MA: MIT Press.

Schmidt, A. (2018). Comics experience guide to writing comics: Scripting your story ideas from start to finish. Exeter, UK: Impact Books.

Sousanis, N. (2015a). Grids and gestures: A comics making exercise. SANE Journal: Sequential Art Narrative in Education, 2(1), Article 8.

Sousanis, N. (2015b). Unflattening. Cambridge, MA: Harvard University Press.

Thompson, R. (2018). Writing through comics. In A. Burger (Ed.), Teaching graphic novels in the English classroom: Pedagogical possibilities of multimodal literacy engagement (pp. 43-66). New York: Palgrave Macmillan.

Webb, L. (2014). History of American education: Voices and perspectives. San Diego, CA: Bridgepoint Publishing.

Weiner, E. J. (2007). Critical pedagogy and the crisis of the imagination. In P. McLaren \& J. L. Kincheloe (Eds.), Critical pedagogy: Where are we now? (pp. 57-78). New York: Peter Lang. 
West Virginia State Board of Education v. Barnette, 319 U.S. 624. (1943). Retrieved from https://supreme.justia.com/cases/federal/us/319/624/\# tab-opinion-1937809.

Westheimer, J., \& Kahne, J. (2004). What kind of citizen? The politics of educating for democracy. American Education Research Journal, 41(2), 237-269.

Wolk, D. (2007). Reading comics: How graphic novels work and what they mean. New York: Da Capo. 